\title{
Proposal of A New Method for Calculating Basic Living Allowance Standard based on Mathematical Modeling
}

\author{
Jing-yan Liu \\ North China Electric Power University in Baoding, Hebei Province, China \\ liujingyan6723@126.com
}

\begin{abstract}
Important policy changes are coordinated into history of 'urban-rural separation, urban and rural coordination as well as urban and rural unifying' in urban and rural basic living allowance system development process in China (important policy nodes of urban and rural basic living allowance development). Once registered permanent residence reform is fully implemented, various provinces and cities will encounter the following problems: education problem, urban and rural basic living allowance standard policy coordination problem, etc. In the paper, a new method for calculating basic living allowance standards based on mathematical modeling was proposed, the method is introduced major in three parts: 32 provinces and cities were divided into three categories, and typical provinces were selected among various categories in the first part. Basic living allowance standards were calculated for typical provinces and cities of different categories in the second part. Basic living allowance standards were calculated for populations in different categories in the same province or city in the third part. Some other suggestions were proposed in the third part.

Index Terms - Cluster analysis; Urban and rural co-ordination; Urban and rural co-ordination
\end{abstract}

\section{Introduction}

New registered permanent residence reform produces three major system impacts on existing urban-rural separation basic allowance system, namely three major contentsabolishing of registered permanent residence difference registration system, new round of orderly urbanization, residence certificate and corresponding public service in new registered permanent residence reform have impact on existing urban-rural separation basic allowance system, new registered permanent residence reform leads to impact on regions of three categories, namely region with massive inflow of population, region with high pressure of agricultural population urbanization transfer and poor grassroots region. Therefore, a new method for calculating basic living allowance standards was proposed based on mathematical modeling in the paper.

\section{Province Classification and Selection of Typical Provinces}

Urban basic living allowance standard formulation is a complex and systematic work task. It should be based on social development condition, market price level, general citizen living standards, economic development level, etc. under the precondition of maintaining the minimum living needs. In summary, urban resident basic living allowance standards are formulated mainly based on the following criteria: (1) item categories and quantity demanded for maintaining resident minimum living needs; (2) costs of living necessities (3) Market comprehensive price index, especially price index for living necessities; (4) the average real income and consumption level of residents; (5) economic development condition and fiscal income condition; (6) other social security standards [1].

SPSS was utilized for cluster analysis based on similarity of these factors in various provinces and cities. 31 provinces and cities in China were divided into three categories. Category I: Shanghai, Beijing, Tianjin, Jiangsu, Zhejiang, Inner Mongolia Autonomous Region, Guangdong Province, Liaoning Province, Shandong Province and Fujian Province. Category II: Jilin, Hebei, Hubei, Chongqing, Shaanxi, Heilongjiang Province, Ningxia Hui Autonomous Region, Shanxi Province, Xinjiang Uygur Autonomous Region and Hunan Province. Category III: Henan Province, Qinghai, Hainan, Jiangxi, Sichuan, Anhui Province, Guangxi Zhuang Autonomous Region, Tibet Autonomous Region, Gansu, Yunnan and Guizhou.

Zhejiang Province was selected as calculation object in the paper among category I regions. Jilin province was selected as calculation object in the paper in category II regions. Qinghai Province was selected as calculation object in the paper in category III regions.

\section{Regional Difference -Different Calculation Formulas were Adopted for Provinces and Cities in Different Categories}

The main consumption expenditure of residents includes eight categories of food, clothing, household equipment articles and services, health care, transportation and communication, education cultural and recreational services, housing, miscellaneous goods and services [2]. In the paper, marginal propensity analysis was utilized for obtaining main consumption expenditure tendencies of residents in different regions according to real basic living allowance standards of different categories, thereby objectively weighting major consumption expenditure items in representative regions of the three categories, and obtaining a method for calculating basic living allowance standards based on mathematical modeling. Basic living allowance calculation formulas and specific basic living allowance standards in all provinces and cities were obtained. Marginal propensity propensity of residents on various consumption goods can reflect order of various consumption demands and newly-increased purchasing power direction of residents. It is basic indicator used as basis of 
adjusting industrial structure and product structure [2].

It is known that transportation and communications marginal consumption propensity was the highest- 0.134 according to related data through the marginal propensity analysis in Zhejiang Province. The result showed that people in Zhejiang Province had increasingly frequent and close contact on one hand, high cost of transport and communication in Zhejiang Province also can be reflected on the other hand. Food consumption item was in the second place- 0.09 , which was followed by education cultural and recreational services0.084 . Obviously, urban resident living standard was gradually increased in Zhejiang Province, and they began to enjoy spiritual civilization life gradually. Meanwhile, it is obvious that people in Zhejiang Province invested more in learning and education for their children and themselves. Clothing consumption was 0.057 , it indicated that more and more people started to pursue high-quality life in Zhejiang Province. Other consumer items had lower consumption propensity, such as household equipment, it was obvious that demand for appliances in Zhejiang province had been basically saturated, and resident consumption was more reasonable. The marginal consumption propensity on health care and miscellaneous goods or services was low, the result indicated that rural residents in Zhejiang Province had lower consumption level in health care and high level life enjoyment, which should be further strengthened. The above analysis reflected that main consumption expenditures of Zhejiang residents were mainly concentrated in four aspects of transport and communications, food, education cultural and recreational services, and clothing.

In Jilin Province, the following information was obtained according to related data through marginal propensity analysis: the marginal consumption propensity of health care was 0.144 , and it was the highest value among all consumption items. It was obvious that local residents paid more attention to their own health. It was followed by food (0.132) and clothing consumption (marginal consumption propensity is 0.103 ), Jilin Province is located in the northern cold regions, local weather is always colder than other places in China. Therefore, people need some cold and warm clothes to keep warm. The demand in other areas was more even in addition to the three main categories of consumption. Therefore, these eight major categories of demands should be fully considered during formulation of basic living allowance standards.

In Qinghai Province, the following information was obtained according to related data through marginal propensity analysis: the highest marginal consumption propensity was food, which was up to 0.144 and the highest among all consumption items. Food constituted major consumption item in urban resident expenditure of Qinghai Province, which was followed by health care with marginal consumption propensity of 0.085 . The result showed that local residents also paid more attention to their health. The third place was clothing with marginal consumption propensity of 0.071 . Local residents had fewer consumption on other consumption items. Therefore, it was obvious that main consumption items of urban residents in Qinghai Province were mainly concentrated on food, medical care, clothing, transport and communications, education culture and entertainment services.

Provinces in category I was the most economically developed, and main consumption items were concentrated in four aspects of transport and communications, food, education cultural and recreational services as well as clothing according to the above analysis. Provinces in the category II were more developed. Therefore, these eight major categories of demands should be fully considered during formulation of basic living allowance standards. Provinces in the category III were backward in economy, and main consumption items were concentrated in five categories of food, health care, clothing, transport and communications, education cultural and entertainment.

The results are shown in the following table through continuous testing:

TABLE 1 Results of Provinces in Category I

\begin{tabular}{|c|c|c|}
\hline Consumption Item & Transport and Communications & Food \\
\hline Weight & 0.367 & 0.247 \\
\hline Consumption Item & Education Cultural and Entertainment Services & Clothing \\
\hline Weight & 0.230 & 0.156 \\
\hline
\end{tabular}

TABLE 2 Results of Provinces in Category II

\begin{tabular}{|c|c|c|}
\hline Consumption Item & Health Care & Food \\
\hline Weight & 0.226 & 0.208 \\
\hline Consumption Item & Clothing & Household Equipment Items and Services \\
\hline Weight & 0.162 & 0.094 \\
\hline Consumption Item & $\begin{array}{c}\text { Transport and } \\
\text { Communications }\end{array}$ & $\begin{array}{c}\text { Education Cultural and Entertainment } \\
\text { Services }\end{array}$ \\
\hline Weight & 0.093 & 0.085 \\
\hline Consumption Item & Housing & Miscellaneous Goods and Services \\
\hline Weight & 0.064 & 0.068 \\
\hline
\end{tabular}

TABLE 3 Results of Provinces in Category III

\begin{tabular}{|c|c|c|}
\hline Consumption Item & Food & Health Care \\
\hline Weight & 0.388 & 0.207 \\
\hline Consumption Item & Clothing & Transport and Communications \\
\hline Weight & 0.173 & 0.127 \\
\hline Consumption Item & $\begin{array}{c}\text { Education Cultural and } \\
\text { Entertainment Services }\end{array}$ & \\
\hline Weight & 0.105 & \\
\hline
\end{tabular}

Basic living allowance standard formulas of provinces and cities in three categories were given as follows:

Basic living allowance standard of provinces in category $\mathrm{I}=$ Transport and Communications $* 0.367+$ Food $* 0.247+$ Education Cultural and Entertainment Services $* 0.23+$ Clothing *0.156 ;

Basic living allowance standard of provinces in category $\mathrm{II}=$ Health $\quad$ Care*0.226+Food $* 0.208+$ Clothing*0.162+Household Equipment Items and Services *0.094+Transport and Communications $* 0.093+$ Education Cultural and Entertainment Services *0.085+Housing *0.064+Miscellaneous Goods and Services *0.068 ; 
Basic living allowance standard of provinces in category III =Food *0.388+Health Care *0.207+Clothing $* 0.173+$ Transport and Communications*0.127+Education Cultural and Entertainment Services *0.105 ;

Since units of various consumption items were inconsistent, all data underwent data standardization here. Unit of the basic living allowance standard is ten thousand yuan per person .

\section{Population Difference-with Zhejiang Province as Example}

2010 resident household basic situations in Zhejiang Province were classified into seven equal parts according to resident income. Residents were divided into households with the lowest income, households with low income, households with lower middle income, households with middle income, households with upper middle income, households with high income and households with the highest income. Eight consumption items were completely considered. Weights were determined as follows on the basis of data in 'Zhejiang Province 2011 Statistical Yearbook' and according to proportion of each consumption item in total consumption expenditure:

TABLE 4 Results of Households with the Lowest Income

\begin{tabular}{|c|c|c|}
\hline Consumption Item & Food & Clothing \\
\hline Weight: & 0.467 & 0.075 \\
\hline Consumption Item & Housing & $\begin{array}{c}\text { Household Equipment Items } \\
\text { and Services }\end{array}$ \\
\hline Weight: & 0.090 & 0.033 \\
\hline Consumption Item & Health Care & Transport and Communications \\
\hline Weight: & 0.085 & 0.100 \\
\hline Consumption Item & $\begin{array}{c}\text { Education Cultural } \\
\text { and Entertainment }\end{array}$ & $\begin{array}{c}\text { Miscellaneous Goods and } \\
\text { Services }\end{array}$ \\
\hline Weight: & 0.131 & 0.016 \\
\hline
\end{tabular}

TABLE 5 Households with Low Income

\begin{tabular}{|c|c|c|}
\hline Consumption Item & Food & Clothing \\
\hline Weight: & 0.402 & 0.085 \\
\hline Consumption Item & Housing & $\begin{array}{c}\text { Household Equipment Items } \\
\text { and Services }\end{array}$ \\
\hline Weight: & 0.084 & 0.035 \\
\hline Consumption Item & Health Care & Transport and Communications \\
\hline Weight: & 0.055 & 0.198 \\
\hline Consumption Item & $\begin{array}{c}\text { Education Cultural } \\
\text { and Entertainment }\end{array}$ & $\begin{array}{c}\text { Miscellaneous Goods and } \\
\text { Services }\end{array}$ \\
\hline Weight: & 0.119 & 0.020 \\
\hline
\end{tabular}

TABLE 6 Households with Lower Middle Income

\begin{tabular}{|c|c|c|}
\hline Consumption Item & Food & Clothing \\
\hline Weight: & 0.395 & 0.096 \\
\hline Consumption Item & Housing & $\begin{array}{c}\text { Household Equipment Items } \\
\text { and Services }\end{array}$ \\
\hline Weight: & 0.085 & 0.046 \\
\hline Consumption Item & Health Care & Transport and Communications \\
\hline Weight: & 0.066 & 0.155 \\
\hline Consumption Item & $\begin{array}{c}\text { Education Cultural } \\
\text { and Entertainment }\end{array}$ & $\begin{array}{c}\text { Miscellaneous Goods and } \\
\text { Services }\end{array}$ \\
\hline Weight: & 0.119 & 0.136 \\
\hline
\end{tabular}

TABLE 7 Households with Middle Income

\begin{tabular}{|c|c|c|}
\hline Consumption Item & Food & Clothing \\
\hline Weight: & 0.389 & 0.093 \\
\hline Consumption Item & Housing & $\begin{array}{c}\text { Household Equipment Items } \\
\text { and Services }\end{array}$ \\
\hline Weight: & 0.076 & 0.047 \\
\hline Consumption Item & Health Care & Transport and Communications \\
\hline Weight: & 0.065 & 0.171 \\
\hline Consumption Item & $\begin{array}{c}\text { Education Cultural } \\
\text { and Entertainment }\end{array}$ & $\begin{array}{c}\text { Miscellaneous Goods and } \\
\text { Services }\end{array}$ \\
\hline Weight: & 0.134 & 0.025 \\
\hline
\end{tabular}

TABLE 8 Households with Upper Middle Income

\begin{tabular}{|c|c|c|}
\hline Consumption Item & Food & Clothing \\
\hline Weight: & 0.340 & 0.103 \\
\hline Consumption Item & Housing & $\begin{array}{c}\text { Household Equipment Items } \\
\text { and Services }\end{array}$ \\
\hline Weight: & 0.082 & 0.051 \\
\hline Consumption Item & Health Care & Transport and Communications \\
\hline Weight: & 0.057 & 0.196 \\
\hline Consumption Item & $\begin{array}{c}\text { Education Cultural } \\
\text { and Entertainment }\end{array}$ & $\begin{array}{c}\text { Miscellaneous Goods and } \\
\text { Services }\end{array}$ \\
\hline Weight: & 0.142 & 0.028 \\
\hline
\end{tabular}

TABLE9 Households with High Income

\begin{tabular}{|c|c|c|}
\hline Consumption Item & Food & Clothing \\
\hline Weight: & 0.304 & 0.118 \\
\hline Consumption Item & Housing & $\begin{array}{c}\text { Household Equipment Items } \\
\text { and Services }\end{array}$ \\
\hline Weight: & 0.078 & 0.057 \\
\hline Consumption Item & Health Care & Transport and Communications \\
\hline Weight: & 0.061 & 0.182 \\
\hline Consumption Item & $\begin{array}{c}\text { Education Cultural } \\
\text { and Entertainment }\end{array}$ & $\begin{array}{c}\text { Miscellaneous Goods and } \\
\text { Services }\end{array}$ \\
\hline Weight: & 0.160 & 0.038 \\
\hline
\end{tabular}

TABLE 10 Households with The Highest Income

\begin{tabular}{|c|c|c|}
\hline Consumption Item & Food & Clothing \\
\hline Weight: & 0.251 & 0.107 \\
\hline Consumption Item & Housing & $\begin{array}{c}\text { Household Equipment Items } \\
\text { and Services }\end{array}$ \\
\hline Weight: & 0.072 & 0.065 \\
\hline Consumption Item & Health Care & Transport and Communications \\
\hline Weight: & 0.040 & 0.257 \\
\hline Consumption Item & $\begin{array}{c}\text { Education Cultural } \\
\text { and Entertainment }\end{array}$ & $\begin{array}{c}\text { Miscellaneous Goods and } \\
\text { Services }\end{array}$ \\
\hline Weight: & 0.163 & 0.045 \\
\hline
\end{tabular}

The basic living allowance standard calculation formulas of households in the seven categories are given as follows:

Basic living allowance standard $=$ Food $*$ Corresponding Weight + Clothing *Corresponding Weight + Housing *Corresponding Weight + Household Equipment Items and Services *Corresponding Weight + Health Care*Corresponding Weight + Transport and Communications $*$ Corresponding Weight + Education Cultural and Entertainment *Corresponding Weight + Miscellaneous Goods and Services *Corresponding Weight;

Since units of various consumption items were inconsistent, all data underwent data standardization here. Unit 
of the basic living allowance standard is ten thousand yuan per person.

\section{Conclusion}

Establishment of rescuing standard dynamic adjustment mechanism should be adhered. Unified basic living allowance standard dynamic adjustment mechanism should be established according to social real per capita living standards, minimum cost necessary for maintaining survival, price increase index, economic development level, government financial conditions and other factors. Contents of adjustment mechanism includes adjustment time, adjustment frequency, adjustment extent, funding source, etc. The following aspects should be noticed during adjustment: firstly, adjustment method should be unified, secondly, adjustment time should be prevented from fixed order so that urban and rural basic living allowance standards can be synchronously adjusted; Furthermore, the adjustment should be based on uniform increase proportion in adjustment extent. Finally, gap between rural and urban basic living allowance standards should be further shortened in system design.

\section{References}

[1] What are main basis for urban basic living allowance standards? http://www.china.com.cn/city/txt/2006-11/27/content_7414759.htm

[2] Liu Tiancheng Research on urban basic living allowance standard calculation method in China- calculation based in Zhejiang, Jilin and Qinghai. Graduate School of North China Electric Power University, 2012. 